\title{
METHOD FOR ASSESSING THE CARBON FOOTPRINT OF MARITIME FREIGHT TRANSPORT: EUROPEAN CASE STUDY AND RESULTS
}

\author{
Jacques Leonardi, Michael Browne \\ University of Westminster, Department for Transport Studies
}

\section{Introduction}

An approach has been developed to analyse and collect data, and to measure energy use and GHG emissions in global logistics activities for product supply chains. This approach has been used to assess the GHG efficiency of several supply chains for furniture and fruit (apples) and vegetables, and one part of this approach was dedicated to the comparison of different international shipping lines, and logistics options. The vessels observed in the case studies are carrying deep sea containers for European import trade on standard international maritime routes.

\section{Review of relevant literature, problem description and objectives of this study}

There is an important world wide debate on the climate impact of global maritime freight, and how to mitigate it (IMO 2008); there is also a global discussion on carbon accounting in product supply chains, leading to recent data collection studies (Edwards et al 2009). Both research fields offer very good reasons to continue to search for solutions in providing good data and innovative findings on the carbon footprint of maritime freight transport, mainly because the magnitude of the maritime contribution to total transport emissions is rather high, and little improvement has been reported so far, such as economy of scale of efficient large vessels (Cullinane and Khanna, 1999), or lower speed leading to fuel use reduction (Buhaug et al, 2008) or number of vessels deployed per loop (Noteboom \& Vernimmen, 2008). Concerning the data collection in freight transport, there is a debate on continuing to harmonise freight survey methods in Europe using a vehicle approach (Pasi 2008). This has led to more precise data collection methods in the frame of national continuous surveys. However, according to recent developments, the inclusion of maritime fuel use data in these European freight transport statistics is targeted, but not expected in short term. This data gap therefore remains current.

There is also an international debate on how to improve the data collection in freight transport in order to better integrate climate change and energy use values into transport statistics (McKinnon and Leonardi, 2009). The problem is that the political decision makers do not rely on robust data sources and statistics concerning fuel use in international supply chains, as it would be the case for many other economic questions. There is a specific need for more data and original field survey work, identified in many previous studies. Since the supply chain approach is a time consuming survey activity, the data needs can be covered in the short term only through a case study and a product specific method.

On another level, there is a more general debate on green logistics and its implications for technology, organisations, supply chains and fuel use. A core question in this field is to assess the different solutions and potential developments in order to provide guidance leading to a more sustainable logistics. This study is delivering a contribution to this field by providing new data and a new approach.

In this context, the objective of this paper is to offer an answer to specific questions that show some links to all these debates: how to better quantify the maritime freight efficiency? And what are the lessons learnt of the outcomes of a carbon footprint survey using a supply chain approach for this sector? Can we recommend potential measures as a result of this research?

\footnotetext{
Method

In this study, the GHG efficiencies of the supply chains are expressed in gram $\mathrm{CO}_{2}$ equivalent per kilogramme of product $\left(\mathrm{gCO}_{2} \mathrm{e} / \mathrm{kg}\right)$. This central indicator is quantified according to primary data collection efforts conducted in the maritime, retail and wholesale sectors in UK, France and Belgium in 2008, and following a standardised carbon auditing and calculation method. Then the results were compared for all supply chains. For food products, the limit of the system observed is considering all logistics steps and energy use activities from the orchard or farm, where they are grown, up to the consumer's home. For furniture, the case study starts from the production plant and ends at the home of the final consumer (Rizet et al 2008). In both products, and in the different international supply chains, the relative importance of the maritime sector appears to be rather high, depending on the assumptions for the final consumer leg.
} 
The general results of this survey are published in a report, presenting the full methodology (Rizet et al, 2008). Here, the focus is on the method used for data collection and analysis of the maritime transport, and on the innovative parts of it compared to previous studies.

One of the main purposes of this study was to provide additional primary observations to complement existing literature. This has been achieved by preparing several case studies on products, observing actual trips of typical vessels on very frequently used ocean shipping routes between New Zealand, Asia and Europe and between Brazil and Europe.

The surveys on the logistics of maritime supply chains were designed according to the objectives:

- to identify typical supply chain configurations and the patterns of maritime transport in it;

- to quantify the energy consumption of the transport legs, including one of the longest possible maritime transport trip;

- to understand the mechanisms leading to better performance in some cases;

- to evaluate the potential for future efficiency gains in the supply chains.

The system observed here has clear limits. The focus is on GHG emissions of the physical transport, not on storage or other production, logistics, service or trade activities. The economic activities are those represented by a carrier, which responsibility starts while taking the deep sea container on board the vessel at a port of origin, and delivering it to another port at destination, according to a commonly used trade practice. Therefore the observation of the maritime transport carbon footprint starts in the port of origin and ends up in the port of destination.

\section{Emission and conversion factors for maritime fuel}

The GHG emissions are calculated by applying the conversion factors for heavy fuel and $\mathrm{CO}_{2}$ equivalents, using to some extend the methodology of Defra (2008). This methodology includes into the calculation of a mean $\mathrm{CO}_{2}$ equivalent also some indirect effects of emissions generated by the oil industry for bringing the fuel to the filling station, following Ademe (2007). This is about $+13 \%$ of the emission factor of the combustion only. The emission factor used to convert maritime heavy fuel oil (HFO type ISO 380) into carbon dioxide is:

$1 \mathrm{~kg} \mathrm{HFO}=3553$ grams $\mathrm{CO}_{2}$ equivalent $\left(\mathrm{g} \mathrm{CO}_{2} \mathrm{e}\right)$

Note that this emission factor (1) is about $18 \%$ higher than the 3.02 factor of Buhaug et al (2008). Table 1 gives the details of the calculation of the emission factor for heavy fuel, starting from $1 \mathrm{~kg}$ fuel.

\begin{tabular}{|c|c|c|c|c|c|c|}
\hline & \multirow{3}{*}{$\begin{array}{l}\text { Energy } \\
\text { equivalent } \\
=\text { goe }\end{array}$} & \multicolumn{4}{|c|}{ Emission factor } \\
\hline & & & \multicolumn{2}{|c|}{ Combustion only } & \multicolumn{2}{|c|}{ combustion + supply } \\
\hline & $\mathrm{kg}$ & & $=\mathrm{gCe}$ & $=\mathrm{gCO}_{2} \mathrm{e}$ & $=\mathrm{gCe}$ & $=\mathrm{gCO}_{2} \mathrm{e}$ \\
\hline Heavy Fuel Oil HFO & 1 & 952 & 859 & 3153 & 968 & 3553 \\
\hline Heavy Fuel Oil HFO & & 1 & & & & 3.73214 \\
\hline
\end{tabular}

Table 1: Conversion and emission factors for heavy fuel oil, used in this study Sources: Ademe, 2007, Defra, 2008

The abbreviations are: $\mathrm{g} \mathrm{Ce}=$ gram carbon equivalent $(\mathrm{C}=$ carbon $)$; goe $=$ gram oil equivalent; $\mathrm{gCO}_{2} \mathrm{e}=$ gram carbon dioxide equivalent. Also fundamental is the conversion factor from carbon to carbon dioxide: $1 \mathrm{~kg} \mathrm{C}=3.67 \mathrm{~kg} \mathrm{CO}$.

\section{Estimating energy and GHG emissions efficiencies for maritime freight transport}

In order to relate fuel use to the load, we use the following main indicators:

- Supply chain energy efficiency: Gram of oil equivalent, related to $\mathrm{kg}$ of product (goe $/ \mathrm{kg})$

- Supply chain $\mathrm{GHG}$ efficiency: Gram of $\mathrm{CO}_{2}$ equivalent, related to $\mathrm{kg}$ of product $\left(\mathrm{gCO}_{2} \mathrm{e} / \mathrm{kg}\right)$

- Transport GHG intensity: Gram of $\mathrm{CO}_{2}$ equivalent per transport performance of the vessel in tonne-kilometre $\left(\mathrm{gCO}_{2} \mathrm{e} / \mathrm{tkm}\right)$.

For calculating maritime transport energy, we observed the energy consumed for container transport and the energy used in bulk cargo vessels. 
Estimating energy consumption and GHG emissions of a maritime transport leg between the two ports of origin and destination was not very simple. The shipyards and shipping companies provided data on

- identification of the vessel (name, register year, owner, etc)

- main and auxiliary engine fuel use in tonnes per day at sea, and in tonnes per day in ports,

- nominal capacity in TEU (twenty foot equivalent unit) or in tonnes,

- maritime line and port calls, with number of days at sea and length of each stop,

- mean load factor in \% of the nominal capacity.

Ports authorities provided data on

- mean weight of one TEU in tonnes

From these data, emissions of container vessels were calculated using:

$E i=\frac{((F s \times D s)+(F p \times D p)) \times 1000 \times 3553)}{N \times L \times Q}$

Where:

$\mathrm{Ei}=\mathrm{GHG}$ emission intensity per product unit, in $\mathrm{gCO}_{2} \mathrm{e}$ per $\mathrm{kg}$

$F s=$ Average fuel use (heavy fuel) from the vessel (in tonnes per day at sea)

$F p=$ Average fuel use (heavy fuel) from the vessel (in tonnes per day in ports)

$D s=$ Number of days at sea for the maritime line

$D p=$ Number of days in ports for the maritime line

$N=$ Nominal capacity of the vessel in TEU

$L=$ Load factor, in $\%$ of the nominal capacity (findings: $60 \%$ are loaded container on average)

$Q=$ Load per one TEU in $\mathrm{kg}$ (findings: $10,000 \mathrm{~kg}$, not counting the empty boxes)

$1000=$ Factor from one tonne to one $\mathrm{kg} \mathrm{HFO}$

$3553=$ Emission factor for one $\mathrm{kg} \mathrm{HFO}$ expressed in gram $\mathrm{CO}_{2}$ equivalent (cf. Table 1)

Additional information was collected in order to better understand the values for these indicators: port calls and shipping line route, nautical miles between ports, vessel load factor in TEU or \% of nominal carrying capacity.

For the case of the bulk vessel observed, it was a direct trip using a charter ship. The calculation followed the same principles as the calculation method (2), but was less complicated.

$$
E i=\frac{F s \times D s \times 1000 \times 3553}{N \times L}
$$

Where:

$\mathrm{Ei}=\mathrm{GHG}$ emission intensity per product unit, in $\mathrm{gCO}_{2} \mathrm{e}$ per $\mathrm{kg}$

$\mathrm{Fs}=$ Average fuel use (heavy fuel) efficiency of the vessel (in tonnes per day at sea)

Ds $=$ Number of days at sea for this maritime line

$\mathrm{N}=$ Nominal capacity of the vessel in tonnes

$L=$ Load factor, expressed in \% of the nominal capacity 
$14^{\text {th }}$ Annual Logistics Research Network Conference, $9^{\text {th }}-11^{\text {th }}$ September 2009, Cardiff

\begin{tabular}{|c|c|c|c|c|c|c|c|c|c|c|c|}
\hline \multirow{3}{*}{\begin{tabular}{|l|} 
Product \\
Type of vessel \\
Type of trip
\end{tabular}} & \multicolumn{5}{|c|}{ Fruits: Apples } & \multicolumn{6}{|c|}{ Furniture: Drawer chest } \\
\hline & & & Container & & Bulk & & & Container & & & \\
\hline & $\begin{array}{l}\text { Feeder } \\
\text { line }\end{array}$ & Ocean line & Ocean line & Total trip & $\begin{array}{l}\text { Direct trip } \\
\text { charter }\end{array}$ & $\begin{array}{l}\text { Effects } \\
\text { in \% }\end{array}$ & $\begin{array}{l}\text { Total } \\
\text { trip }\end{array}$ & Ocean line & Line hub service & Total trip & $\begin{array}{l}\text { Effects in } \\
\%\end{array}$ \\
\hline Origin & Nelson & Auckland & Pelabuhan & Nelson & Nelson & Nelson & Itajai & Itajai & Algeciras & Itajai & Itajai \\
\hline Destination & Auckland & Pelabuhan & $\begin{array}{l}\text { Felixstowe/ } \\
\text { Antwerp }\end{array}$ & \begin{tabular}{|l|} 
Felixstowe/ \\
Antwerp
\end{tabular} & Sheerness & $\begin{array}{l}\text { Felix. or } \\
\text { Sheer. }\end{array}$ & $\begin{array}{l}\text { Le } \\
\text { Havre }\end{array}$ & Algeciras & $\begin{array}{l}\text { Felixstowe/ } \\
\text { Antwerp }\end{array}$ & $\begin{array}{l}\text { Felixstowe/ } \\
\text { Antwerp }\end{array}$ & $\begin{array}{l}\text { Le Havre } \\
\text { or Felix. }\end{array}$ \\
\hline Distance $(\mathrm{km})$ & 1172 & 9440 & \begin{tabular}{|r|}
$15,142^{*}$ \\
\end{tabular} & 25,754 & 21,039 & -18 & 9677 & 8114 & 2752 & 10886 & +12 \\
\hline $\begin{array}{l}\text { Nominal capacity in } \\
\text { TEU }\end{array}$ & 379 & 4112 & 6200 & & & & 3430 & 2824 & 2840 & 2832 & -17 \\
\hline $\begin{array}{l}\text { Mean load factor in } \\
\% \text { of vessel capacity }\end{array}$ & 60 & 60 & 60 & 60 & & & 60 & 60 & 60 & 60 & 0 \\
\hline Tonnes /loaded TEU & 10 & 10 & 10 & & & & 10 & 10 & 10 & 10 & 0 \\
\hline Tonnes loaded & 2274 & 24,672 & 37,200 & & 6259 & & 20,580 & 16,944 & 17,040 & 16,992 & -17 \\
\hline t. HFO/day at sea & 28 & 160 & 246 & & 41.5 & & 103 & 74.9 & 74.9 & 74.9 & -27 \\
\hline t. HFO/day in port & & 13 & 16 & & 2.5 & & 30 & 16.3 & 16.3 & 16.3 & -46 \\
\hline Speed in knots & 9.8 & 16.3 & 17.3 & 16.4 & 17.5 & & 14.0 & 17.7 & 18.8 & 18.0 & +28 \\
\hline Days at sea & 2.7 & 13 & 19.7 & 35.4 & 27 & -24 & 15.5 & 10.3 & 3.3 & 13.6 & -12 \\
\hline Days in ports & & 6 & 2.7 & 8.7 & 6.5 & & 2.9 & 2.2 & 1.8 & 4.0 & +38 \\
\hline Fuel use of ship (toe) & 72 & 2058 & 4657 & 6787 & 1083 & & 1520 & 734 & 235 & 968.6 & -36 \\
\hline $\begin{array}{l}\text { Emissions of ship } \\
\left(\mathrm{tCO}_{2} \mathrm{e}\right)\end{array}$ & 268.6 & 7391 & 17,219 & 24,878 & 3981 & & 5672.4 & 2738.8 & 876.0 & 3614.8 & -36 \\
\hline $\begin{array}{l}\text { Energy efficiency per } \\
\text { TEU, toe/TEU }\end{array}$ & 0.316 & 0.834 & 1.252 & 2.403 & & & 0.739 & 0.433 & 0.138 & 0.570 & -23 \\
\hline $\begin{array}{l}\text { Efficiency (koe / TEU } \\
/ 100 \mathrm{~km} \text { ) }\end{array}$ & 27.0 & 8.8 & 8.3 & 9.3 & & & 7.6 & 5.3 & 5.0 & 5.2 & -31 \\
\hline $\begin{array}{l}\text { Energy intensity } \\
\text { (goe/tkm) }\end{array}$ & 27.0 & 8.8 & 8.3 & 9.3 & 8.2 & -12 & 7.6 & 5.3 & 5.0 & 5.2 & -31 \\
\hline $\begin{array}{l}\text { GHG intensity } \\
\left(\mathrm{gCO}_{2} \mathrm{e} / \mathrm{tkm}\right)\end{array}$ & 101 & 33 & 31 & 35 & 31 & -12 & 28 & 20 & 19 & 20 & -31 \\
\hline $\begin{array}{l}\text { Energy efficiency in } \\
\text { goe/kg }\end{array}$ & 31.6 & 83.4 & 125.2 & 240.3 & 173 & -28 & 73.9 & 43.3 & 13.8 & 57.1 & -23 \\
\hline $\begin{array}{l}\mathrm{Ei}=\mathrm{GHG} \text { efficiency } \\
\text { in } \mathrm{gCO}_{2} \mathrm{e} / \mathrm{kg}\end{array}$ & 118 & 300 & 463 & 881 & 636 & -28 & 276 & 162 & 51 & 213.0 & -23 \\
\hline
\end{tabular}

Source: own data collection, survey $2007 \& 2008$

* Note: Trips to Felixstowe and to Sheerness are compared in the column 'effects'. The \% change is calculated as difference from the trip to Felixstowe.

Trips to Le Havre and to Felixstowe/Antwerp are compared for furniture. The \% change is calculated as difference from the trip to Le Havre. 


\section{Results}

For the apple supply chain, the origin was the region of Nelson in New Zealand and the destination was Felixstowe or Antwerp for the container vessels and Sheerness for the bulk carrier vessel.

For furniture, the production of the drawer chest was in Brazil. The port of origin was Itajai and destination was Le Havre, Felixstowe or Antwerp. Two routes were used; the first with a stop at the hub in Algeciras and a transhipment to another vessel; the second with a direct trip using one vessel going to Le Havre after 9 port calls. For a complete chain description and source documentation, see Rizet et al. (2008). The results are presented in Table 2.

Figure 1 presents the results for GHG efficiency of the observed maritime supply chains. Since the vessels calling at both ports Antwerp or Felixstowe are arriving first either in Antwerp or in Felixstowe, depending on the line schedule, it has been deduced that there is no major difference in the mean distance of the trips ending there. The results presented in Figure 1 are based on Table 2 values.

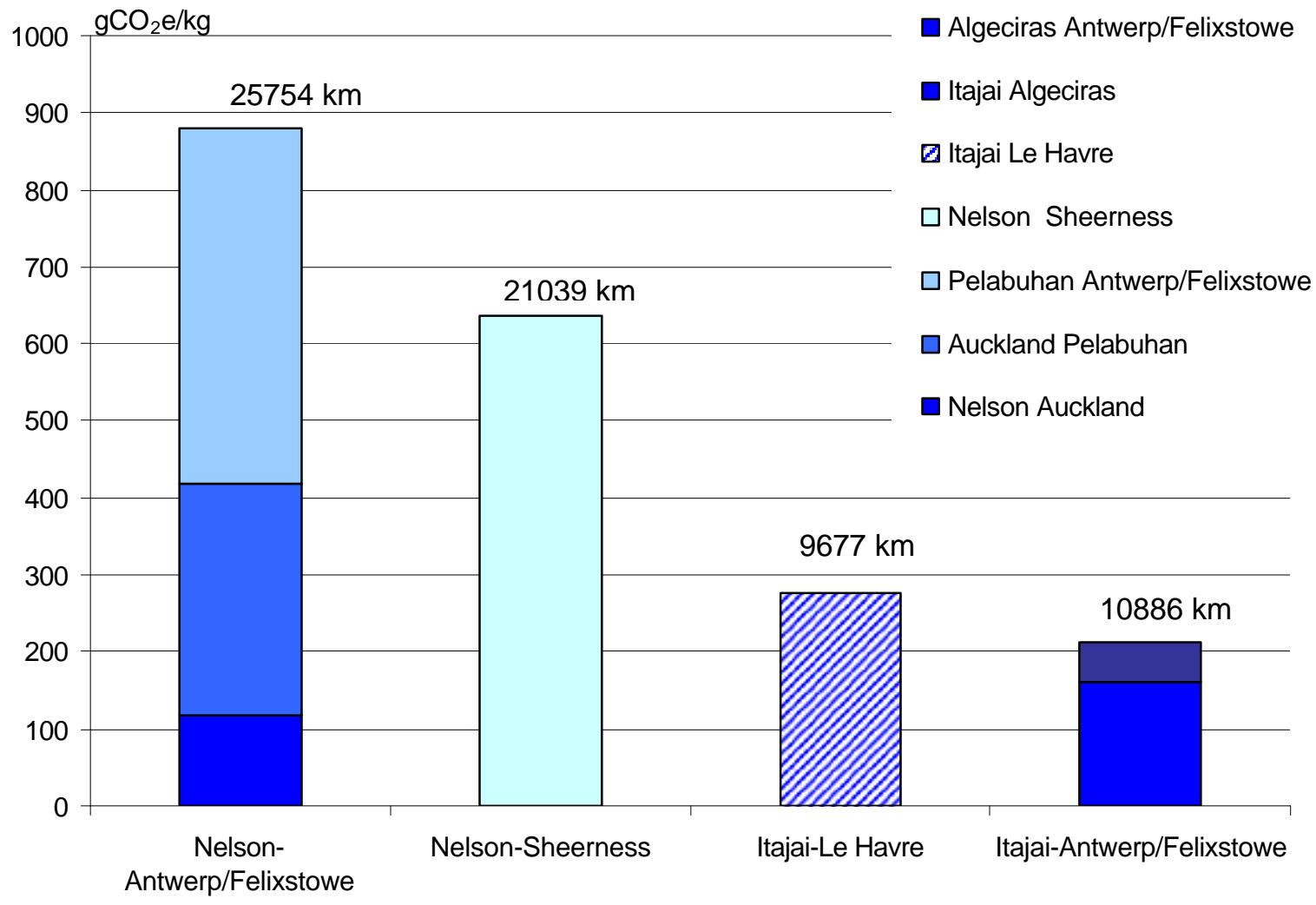

Figure 1: Comparison of the greenhouse gas emission intensity of the six maritime supply chains Source: own data collection, 2008

In order to understand the effect of logistics choices on the carbon footprint of the maritime transport, it is useful to look more closely to the details of the findings and to the logistics processes observed. Instead of sending the fruits per container, the shipper can use a charter vessel for the transport of apples from New Zealand to Europe. It only takes 27 days at sea instead of $35(-24 \%)$. The shorter time and the fact of having no interruption in the cool chain, result in a final delivery in UK in high quality. Because the charter vessel is travelling directly without port calls and passing through the Panama Canal instead of the Malacca Strait, it shortens the sea trip distance by more than $4700 \mathrm{~km}$, corresponding to about $-18 \%$ (Table 2). The transport GHG intensity factor of 31 gram carbon dioxide equivalent per $\mathrm{kg}$ product for the charter vessel is equivalent to the intensity factor of one larger container vessel observed, but the shorter time made then a reduction of about $28 \%$ in the overall supply chain $\mathrm{GHG}$ intensity, measured in $\mathrm{gCO}_{2} \mathrm{e} / \mathrm{kg}$ (Figure 1).

Another lesson can be learnt from the trip variations from the South America supply chain. In one case, the shipment is sent via a shipping line, with one vessel stopping at Itajai and Le Havre, delivering to the French furniture market. The other type of shipping is using a hub port in Algeciras, 
$14^{\text {th }}$ Annual Logistics Research Network Conference, $9^{\text {th }}-11^{\text {th }}$ September 2009, Cardiff

where the containers are unloaded for transhipment, before continuing to Antwerp or Felixstowe. This trip, using a hub, is slightly faster, with about $12 \%$ less days at sea. The main reason for this increased time performance is the reduction of the number of port calls. The vessels in use for the line service Itajai-Algeciras and Algeciras-Felixstowe demonstrate average fuel use efficiency values that are much improved, with about $32 \%$ reduction in $\mathrm{GHG}$ intensity (in $\mathrm{gCO}_{2} \mathrm{e} / \mathrm{tkm}$ ), compared to the line service Itajai-Le Havre. Overall, using the hub port is leading in this case to a reduction in GHG intensity of the supply chain of about $23 \%$ (in $\mathrm{gCO}_{2} / \mathrm{kg}$, Figure 1 ).

\section{Discussion}

Counterintuitive results and main differences with the literature are primarily related to the apparently less strong connexion between the size of the vessels and the GHG intensity per load unit. The conversion factors mentioned in Defra (2008), and Ademe (2007) show far lower values for HFO emissions intensities. These sources show values lower than $10 \mathrm{gCO}_{2} / \mathrm{tkm}$ for container vessels above 2000 TEU capacity. This is less than half of the best vessel observed in this study. These sources also show a clear reduction in specific emission for bigger vessels, that cannot be confirmed here. The emission factor values mentioned in the Lipasto online data collection system (Mäkela 2009) are, however, similar to our findings, with about $34 \mathrm{gCO}_{2} / \mathrm{tkm}$ for a $2000 \mathrm{TEU}$ vessel, with $65 \%$ load factor and 9 tonnes per TEU. The values mentioned in MLTC et al. 2009 are also similar to our findings, with $24 \mathrm{gCO}_{2} / \mathrm{tkm}$ for a $2200 \mathrm{TEU}$ vessel, $80 \%$ load factor and 14 tonnes per TEU including tare weight.

In the case study however, if the values measured in $\mathrm{gCO}_{2} \mathrm{e} / \mathrm{tkm}$ are taken, the most efficient of the six vessels observed was a ship with 2840 TEU nominal capacity, that is travelling slower than the three bigger vessels over 3000 TEU observed. Since the main reason for this good result is the relative low fuel use in tonnes per day at sea compared to the other vessels, an indicator with high level of accuracy (Table 3), there is no reason to assume that a flaw in the data quality is leading to this difference. However, in order to solve this question with robust data, it would be helpful to perform a targeted data collection. In this case, real fuel consumption of shipping lines would be recorded, with two tank fillings, at start and end of the survey.

\section{Uncertainties}

Important uncertainties are occurring during a survey of the type described in this paper. All information that shows a low or medium level of accuracy was obtained from shipping line managers. The margin of error can be high in some crucial points, the most relevant being the mean weight of one container and the mean load factor of the vessels (Table 3). The margin of error of the fuel consumption could also lead to important differences, however, these could not reach a level higher than about $10 \%$.

\begin{tabular}{|l|l|l|}
\hline Indicators & $\begin{array}{l}\text { Accuracy level of the data } \\
\text { obtained }\end{array}$ & Margin of error ( \pm ) \\
\hline Fuel use per day at sea, main engine & High & $<5 \%$ \\
\hline Fuel use per day in ports, main engine & High & $<5 \%$ \\
\hline Fuel use of auxiliary engine & Low & $\begin{array}{l}\text { up to } 10-15 \% \text { of } \\
\text { main engine fuel use }\end{array}$ \\
\hline Tonnes loaded in bulk vessel & Very high & $<2 \%$ \\
\hline $\begin{array}{l}\text { Vessel capacity in TEU } \\
\text { Load factor (loaded container in \% of } \\
\text { nominal capacity) on specific lines }\end{array}$ & Very high & $0 \%$ \\
\hline $\begin{array}{l}\text { Mean weight of one 40' container } \\
\text { (observed loaded container only) }\end{array}$ & how & Few estimates \\
\hline $\begin{array}{l}\text { Mean weight of one TEU on specific } \\
\text { shipping lines }\end{array}$ & Low & $<5 \%$ \\
\hline $\begin{array}{l}\text { Empty containers, number of empty } \\
\text { containers in ports }\end{array}$ & very high & Few estimates \\
\hline Number of days at sea & high & $<2 \%$ \\
\hline Number of days in ports & high & up to $10 \%$ \\
\hline
\end{tabular}

Table 3: Uncertainties in the observations of critical indicators for carbon auditing 


\section{Uncertainty with the net load weight of one TEU and the proportion of empty containers}

In our observations, the load weight of one 40 foot container was 20 tonnes for apples and about 20 tonnes for furniture. Since the 40 foot container account for 2 TEU, the weight of one TEU in the case study is assumed to be 10 tonnes. This is a net weight, excluding the tare weight of the loaded container and the empty containers on board. However, this mean value is subject to uncertainties.

In order to compare this value of $10 \mathrm{t}$ with existing sources, the Eurostat port statistics were used (Amerini 2009). Good results were obtained for containers weight in millions tonnes by multiplying the total gross tonnes with the percentage of containers in the total weight (Table 4, column 4). For the calculation of tonnes per TEU, the total container tonnes (column 4) is divided by the number of container in 1000 TEU excluding the empty containers (column 6). Note that gross weight means the container gross weight minus tare weight. The weight of the empty boxes is not counted in the port statistics, but plays a significant role for the fuel use and also for the calculation of the load factor.

\begin{tabular}{|l|l|l|l|l|l|l|l|}
\hline 2006 & $\begin{array}{l}\text { Gross } \\
\text { weight }\end{array}$ & $\begin{array}{l}\text { Gross } \\
\text { weight }\end{array}$ & Containers & $\begin{array}{l}\text { Number of } \\
\text { containers }\end{array}$ & $\begin{array}{l}\text { Number of } \\
\text { containers }\end{array}$ & $\begin{array}{l}\text { \% of } \\
\text { loaded } \\
\text { containers }\end{array}$ & $\begin{array}{l}\text { Weight of one } \\
\text { TEU loaded } \\
\text { container }\end{array}$ \\
\hline & Mio. t & $\begin{array}{l}\text { \% of } \\
\text { container }\end{array}$ & Mio. t & $\begin{array}{l}1000 \text { TEU } \\
\text { incl. empty }\end{array}$ & $\begin{array}{l}\text { 1000 TEU } \\
\text { excl. empty }\end{array}$ & $\begin{array}{l}\text { Tonnes/loaded } \\
\text { TEU }\end{array}$ \\
\hline Rotterdam & 353.6 & 21 & 74.256 & 9575 & 7594 & 79.3 & 9.77 \\
\hline Antwerp & 151.7 & 43 & 65.231 & 6718 & 5714 & 85.1 & 11.41 \\
\hline Hamburg & 115.5 & 61 & 70.455 & 8878 & 7399 & 83.3 & 9.52 \\
\hline Le Havre & 70.0 & 32 & 22.4 & 2119 & 1788 & 84.4 & 12.52 \\
\hline Southampton & 40.6 & 24 & 9.744 & 1502 & 955 & 63.6 & 10.20 \\
\hline
\end{tabular}

Table 4: Mean net weight of one TEU for loaded container

Source: calculated with statistics from Amerini (2009)

The number of containers for Felixstowe was not mentioned in the statistically coherent data of Eurostat (Amerini 2009). The values of 12.52 tonnes for Le Havre and 11.41 tonnes for Antwerp obtained in Table 4 are considered as slightly higher than our results. The Southampton value of 10.2 tonnes per TEU is very similar to our outcomes. Therefore, the uncertainty with the weight of one TEU on the specific supply chain studied is probably not leading to major under- or overestimates of the emission intensities.

The load factor used in the supply chain case study was $60 \%$, this number was obtained from interviews with the manager of the shipping line studied in these supply chains. But this number is subject to uncertainties. In the port statistics of Antwerp and Le Havre, the mean proportion of loaded container is about $85 \%$ of the total TEU. In Southampton, $63.4 \%$ of the containers are loaded (Table 4). This is showing a large difference with other ports, but is still higher than our results. Therefore, the value of $60 \%$ loaded container might be too low. Another source showing container vessel efficiency for Rotterdam is the recently updated database Lipasto (Mäkela, 2009). In this source, the case of a 2000 TEU vessel shows that $65 \%$ of the containers are loaded. The MLTC \& Tecnitas (2009) reports about values for the East Asia - Europe lines varying between 40 and $90 \%$. The values obtained by MLTC \& Tecnitas (2009) are based on an assumed $100 \%$ loaded container, and are at a level of about $17 \mathrm{gCO}_{2} \mathrm{e} / \mathrm{tkm}$, where our results are between 20 and $33 \mathrm{gCO}_{2} \mathrm{e} / \mathrm{tkm}$ for the same type of container vessel. All these sources tend to use values up to $33 \%$ lower and up to $66 \%$ higher than our value of $60 \%$. Therefore, this uncertainty might lead to important under- or overestimates of the observed supply chain GHG emission efficiencies and transport intensities.

\section{Lack of data and open questions}

In the frame of a supply chain study, it was not foreseen to collect data on specific activities like reconfiguration of hub system, adapting cruise speed or introducing new technologies. In order to assess the impact of such measures on the supply chain efficiency, a 'before and after' survey is needed. In such a before and after survey, the record of data must include a period of change, before measuring again the same values than in the analysis of the standard situation. Here the data obtained and the supply chain configuration observed can be considered as elements of analysis of the 'before' situation for future activities. 


\section{Conclusion}

In order to deal with the specific requirements of the maritime sector, an original calculation method was developed. The longest trip observed $(>25700 \mathrm{~km}$ ) was leading to an amount of about 880 grams $\mathrm{CO}_{2}$ equivalent per $\mathrm{kg}$ of product. The least efficient container ship was showing transport $\mathrm{CO}_{2}$ efficiency values of about 100 grams $\mathrm{CO}_{2}$ e per tonne-kilometre. The most efficient vessel observed has reached a value of $19 \mathrm{grams} \mathrm{CO}_{2} \mathrm{e} / \mathrm{tkm}$. By comparing different routes, origins and destinations, and different logistics organisations, it was possible to understand why some options are more favourable than others. The use of a hub is showing good results (-23\% emissions per $\mathrm{kg}$ of product). Also, the use of a charter vessel for a direct trip instead of a container vessel on a shipping line is improving the efficiency by about $28 \%$.

The intended aim of the research has been largely achieved, consisting in providing robust observation values and a feasible calculation method that can be used by decision makers in companies and public sector, in order to allow them to increase the efficiency of the maritime freight transport in the supply chain. The potential for efficiency gains is more clearly identified. This approach can be used in other fields of maritime activity and for assessing other types of measures like new technologies targeting a higher efficiency.

\section{References}

- ADEME - Agence de l'Environnement et de la Maîtrise de l'Energie (2007), Bilan Carbone Entreprises et Collectivités. Guide des facteurs d'émissions. Version 5.0. Calcul des facteurs d'émissions et sources bibliographiques utilisées. Janvier 2007. http://www2.ademe.fr/

- Amerini, G. (2008), Maritime transport of goods and passengers 1997-2007 Statistics in Focus Transport 6/2009 Eurostat Luxembourg

- Buhaug, Ø.; Corbett, J. J.; Endresen, Ø.; Eyring, V.; Faber, J.; Hanayama, S.; Lee, D. S.; Lee, D.; Lindstad, H.; Mjelde, A.; Pålsson, C.; Wanquing, W.; Winebrake, J. J.; Yoshida, K. (2008), Updated Study on Greenhouse Gas Emissions from Ships: Phase I Report; International Maritime Organization (IMO) London, UK

- Cullinane, K.; Khanna, M. (1999), Economies of Scale in Large Container Ships. Journal of Transport Economics and Policy, Vol. 33, No. 2, pp. 185-207

- Defra (2008), Guidelines for Company Reporting on Greenhouse Gas Emissions Annexes Annex 1 - Fuel Conversion Factors, Defra

- Edwards J.B., McKinnon A.C., Cullinane S.L. (2009), Carbon Auditing the 'Last Mile': Modelling the Environmental Impacts of Conventional and Online Non-food Shopping March 2009, Edinburgh, http://www.greenlogistics.org/PageView.aspx?id=76\&tid=76

- Mäkela, K. (2009), Unit emissions of container ships. LIPASTO -calculation system, VTT, http://www.lipasto.vtt.fi/indexe.htm

- McKinnon, A.C.; Leonardi, J. (2009), The Collection of Long Distance Road Freight Data in Europe. in: Lee-Gosselin, M. Zmud, J., Bonnel P., Madre J.-L. (Eds): Transport Survey Methods: Keeping Up with a Changing World.

- MLTC \& Tecnitas (2009), Etude de l'efficacité énergétique et environnementale du transport maritime. Paris

- Notteboom, T.E.; Vernimmen B. (2008), The effect of high fuel costs on liner service configuration in container shipping. Journal of Transport Geography (in press)

- Pasi, S. (2008), Trends in road freight transport 1999 - 2006. Statistics in Focus, Transport 14/2008, Eurostat. Brussels

- Rizet, C., Browne, M., Allen, J., Léonardi, J., Cornélis, E. (2008), Energy Efficiency and Greenhouse Gas Emissions of Different Supply Chains: A Comparison of French, UK and Belgian Cases. European Transport Conference paper 